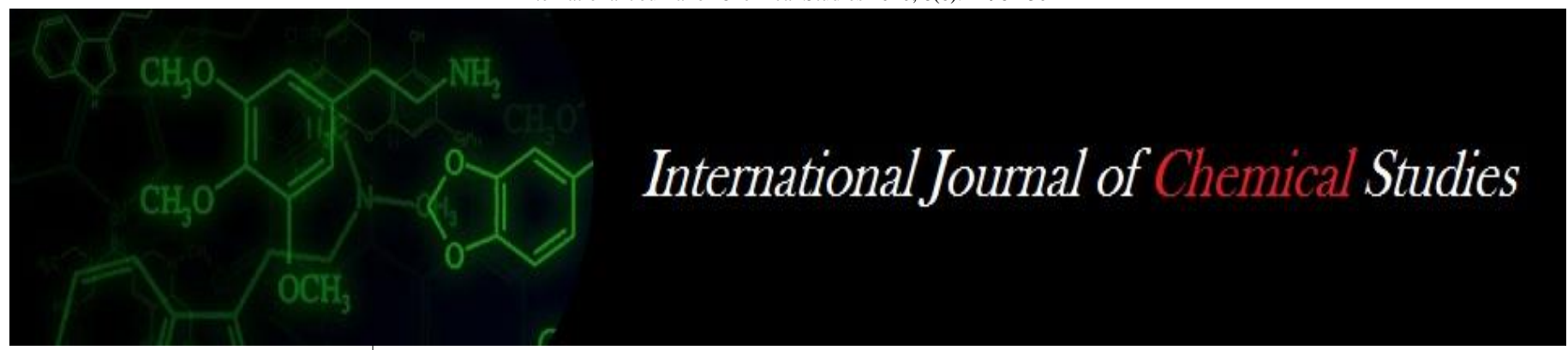

P-ISSN: 2349-8528

E-ISSN: 2321-4902

www.chemijournal.com

IJCS 2020; 8(6): 2298-2301

(C) 2020 IJCS

Received: 15-09-2020

Accepted: 21-11-2020

Arunkumara CG

Department of Agricultural

Entomology, UAS, GKVK

campus, Bengaluru, Karnataka,

India

Jagadish KS

Department of Apiculture, UAS,

GKVK Campus, Bengaluru,

Karnataka, India

Mohan M

ICAR- National Bureau of

Agricultural Insect Resources,

Hebbal, Bengaluru, Karnataka,

India

Venkatesan T

ICAR- National Bureau of

Agricultural Insect Resources,

Hebbal, Bengaluru, Karnataka,

India

Narayanaswamy KC

Department of Sericulture, UAS,

GKVK campus, Bengaluru,

Karnataka, India

Anitha Peter

Department of Plant

Biotechnology, UAS, GKVK

campus, Bengaluru, Karnataka,

India

Corresponding Author:

Arunkumara CG

Department of Agricultural

Entomology, UAS, GKVK

campus, Bengaluru, Karnataka,

India

\section{Biochemical basis of insecticides resistance in cotton leafhopper, Amrasca biguttula biguttula (Ishida) (Hemiptera: Cicadellidae)}

\author{
Arunkumara CG, Jagadish KS, Mohan M, Venkatesan T, \\ Narayanaswamy KC and Anitha Peter
}

DOI: https://doi.org/10.22271/chemi.2020.v8.i6ag.11118

\begin{abstract}
Cotton is one of world's most essential fiber crops having global significance. Several biotic and abiotic stresses are constraints in cotton production including the bollworm complex and sucking pests. Among sucking pests, the cotton leafhopper, Amrasca biguttula biguttula (Ishida) is a devastating pest causing both quantitative and qualitative losses. After the introduction of $B t$ cotton, there was a check to the bollworm complex. But, the sucking pest complex particularly leafhoppers increased gradually reaching economic injury levels. The rampant application of insecticides to control sucking pests has led to the development of pest resistance to insecticides with different mode of action world over. Among the various mechanisms of resistance, the metabolic resistance plays a vital role. In order to determine the enzyme activity viz., cytochrome P450 monooxygenase, carboxyl esterase and glutathione S-transferase, for which the biochemical analysis was done by using field collected and laboratory reared population of this pest. The results revealed that, the activity of detoxification enzymes was significantly higher in the field collected population as compared to the laboratory population. The specific activity of cytochrome $\mathrm{P} 450$ monooxygenase $(14.88 \mathrm{nmol} / \mathrm{min} / \mathrm{mg}$ protein), carboxyl esterase $(1321.97 \mathrm{nmol} / \mathrm{min} / \mathrm{mg}$ protein) and glutathione S-transferase $(1021.83 \mathrm{nmol} / \mathrm{min} / \mathrm{mg}$ protein) in field collected population as compared to cytochrome P450 monooxygenase (12.02 $\mathrm{nmol} / \mathrm{min} / \mathrm{mg}$ protein), carboxyl esterase (1022.82 $\mathrm{nmol} / \mathrm{min} / \mathrm{mg}$ protein) and glutathione S-transferase $(310.26 \mathrm{nmol} / \mathrm{min} / \mathrm{mg}$ protein) in susceptible laboratory reared population of A. biguttula biguttula. This clearly shows that, these three xenobiotic enzymes are responsible for the detoxification of insecticides in the field population of this notorious pest.
\end{abstract}

Keywords: Cotton leafhopper, insecticide resistance, cytochrome P450, carboxylesterase, glutathione Stransferase

\section{Introduction}

Cotton leafhopper, Amrasca biguttula biguttula (Ishida) (Hemiptera: Cicadellidae) is a devastating pest causing both quantitative \& qualitative losses. It is a polyphagous insect pest of cotton, brinjal, okra \& other economically important crops in Asia. After the introduction of $B t$ cotton, there was a check to the bollworm complex. But, the sucking pest population especially leafhoppers increased gradually reaching economic injury level in many parts of India (Mohan and Nandini, 2011) ${ }^{[7]}$.

The pesticide usage on cotton to control the insect pests is both extensive and intensive. The indiscriminate use of insecticides resulted in development of resistance in insects to insecticides and resurgence of sucking pests (Rohini et al., 2012) ${ }^{[10]}$. Introduction of Bt cotton in India in 2002, enabled reduction of insecticide sprays for bollworms, however, this indirectly caused resurgence of sucking pests specially leafhoppers (Kranthi, 2007) ${ }^{[5]}$. The cotton leafhopper developed resistance to the recommended insecticidal groups like neonicotinoids and organophosphates (Kshirsagar et al., 2012) ${ }^{[6]}$. The cotton leafhopper, Amrasca devastans (Distant) was found to have developed resistance to the recommended organophosphate insecticides viz., metasystox, dimethoate and phosphamidon in India (Chalam et al., 1999; Chalam et al., 2001; Praveen, 2003; Santhini and Uthamasamy, 1997) ${ }^{\text {[1] }}$ $[2,9,11]$. Of late, a new group of insecticide viz., neonicotinoids consisting of imidacloprid, thiamethoxam and acetamiprid were found more effective against cotton leafhoppers than 
conventional insecticides. However, in the recent past field level failure of neonicotinoids was noticed in the leafhopper population of Andhra Pradesh. The continuous use of neonicotinoids has probably led to development of resistance. Also, the fact that the $B t$ cotton seeds are available in the market as imidacloprid treated which is giving an impetus for cotton leafhopper to develop resistance against insecticides (Kshirsagar et al., 2012) ${ }^{[6]}$.

Insects develop resistance to insecticides primarily through three mechanisms: decreased penetration, reduced target site sensitivity and enhanced metabolism. Enhanced metabolism of insecticides decreases the attainment of the effective amount of insecticides that can kill insects. Thus, metabolic resistance may significantly decrease the susceptibility of insects to insecticides. Recent studies suggest that arthropod detoxification pathways found to mediate insecticide resistance. Detoxification mechanisms have been studied with special interest in the case of insecticides which involve enzymes such as cytochrome P450 monooxygenase, carboxylesterase and glutathione S-transferase. These play an important role in insecticide resistance in insects.

\section{Material and Methods \\ Collection of test insect}

The present study was conducted at ICAR-NBAIR during 2018-19. The populations of cotton leafhopper nymphs was collected from cotton field in attur farm of NBAIR, Bengaluru and the laboratory susceptible population was maintained since from 2018 in wooden cages on okra plants under net house condition at ICAR-NBAIR, Bengaluru.

\section{Analysis of detoxification enzymes}

The biochemical enzyme assay was carried for the detoxification enzymes like carboxylesterase, GST and cytochrome $\mathrm{P} 450$ monooxygenases for both resistant field and laboratory maintained susceptible populations of $A$. biguttula biguttula in order to determine the genes involved in insecticide resistance.

\section{Enzyme extract preparation}

For cytochrome P450 monooxygenases, carboxylesterase and GST activities, groups of thirty III instar nymphs were homogenised on ice in $1 \mathrm{~mL}$ phosphate buffer $(0.50 \mathrm{M}, \mathrm{pH}$ 7.4). The homogenates were then centrifuged at $10,000 \mathrm{rpm}$ for $15 \mathrm{~min}$ at $4{ }^{\circ} \mathrm{C}$ (Plate 7C) and the supernatant was used as an enzyme source. The crude enzyme extract was used for total protein estimation and three replications were prepared for each enzyme assay.

\section{Total protein estimation}

To estimate the total protein content, the following reagents were prepared; reagent-A consisted of Bradford stock solution (100 $\mathrm{ml}$ of $95 \%$ ethanol, $200 \mathrm{ml}$ of $88 \%$ phosphoric acid and $350 \mathrm{mg}$ of CBB G-250). Reagent-B consisted of Bradford's working buffer $(425 \mathrm{ml}$ distilled water, $15 \mathrm{ml}$ of $95 \%$ ethanol, $30 \mathrm{ml}$ of $88 \%$ phosphoric acid and $30 \mathrm{ml}$ Bradford stock solution. Standard bovine serum albumin 21 (BSA) solution was prepared as $1 \mathrm{mg} / \mathrm{ml}$ in distilled water. The estimation was done by preparation of standard, for this $1 \mathrm{ml}$ of BSA working standard was taken into $1.5 \mathrm{ml}$ Eppendorff tube, the BSA solution was pipetted out and transferred into 10 Eppendorff tubes which contained $0,2.5,5,7.5,10,12.5,15,17.5$ and 20 $\mu \mathrm{l}$ and volume was made upto $100 \mu \mathrm{l}$ using distilled water. The eppendorff tube with $100 \mu$ l distilled water served as the blank. The enzyme sample of $5 \mu \mathrm{l}$ was taken in tubes and made upto $100 \mu \mathrm{l}$. One ml Bradford's working solution was added to all the tubes including blank and enzyme samples and it was vortexed. All the standards were incubated for 10 minutes. Then $300 \mu \mathrm{l}$ was pipetted out into ELISA plates and the absorbance was measured at $595 \mathrm{~nm}$ in ELISA microplate reader (Bio Rad Imark Microplate Reader) (Plate7B) and plotted on the standard graph. Using the standard graph, the linear equation was derived and the sample OD value was extrapolated and the total soluble protein was estimated.

\section{Assay on glutathione S-transferase (GST)}

An amount of $30 \mu \mathrm{l}$ enzyme extract was added to $950 \mu \mathrm{l}$ of $0.5 \mathrm{M}$ phosphate buffer, $\mathrm{pH} 7.4,10 \mu \mathrm{l}$ of $50 \mathrm{mM}$ CDNB in ethanol and $10 \mu \mathrm{l}$ of $50 \mathrm{mM}$ reduced glutathione. The change in optical density was recorded at timed intervals by spectrophotometry at $340 \mathrm{~nm}$. Activity was calculated with an extinction coefficient of $9.6 \mathrm{mM} / \mathrm{cm}$ for CDNB. The Specific activity of enzyme was calculated and expressed as nanomoles of CDNB conjugated per min per mg protein.

The enzyme activity was calculated as follows: CDNB-GSH conjugate formed in nanomoles min-1 mg-1 protein.

$$
=\frac{\Delta \mathrm{A} 340 / \mathrm{min} \times 1000}{9.6 \times \text { protein }(\mu \mathrm{g})}
$$

\section{Assay on carboxylesterase}

The reaction was initiated by adding $15 \mu 1$ enzyme solution (the stock was diluted with $485 \mu \mathrm{l}$ of $0.5 \mathrm{M}$, pH 7.4 sodium phosphate buffer to $1 \mathrm{ml}$ of the mixture solution containing 0.3 $\mathrm{mM} \alpha$-napthyl acetate solution and $1 \%$ fast blue RR salt and $5 \%$ SDS). The optical density at $595 \mathrm{~nm}$ was measured after 20 min by microplate reader. A standard curve was prepared by using $\alpha$-napthol. All the samples were replicated three times. Activity of the enzyme was expressed as nanomoles of $\alpha$-napthol formed per min per miligram protein.

\section{Preparation of $\alpha$-naphthol standard curve}

Stock solution was prepared by using $1 \mathrm{mM}(14.42 \mathrm{mg})$ of $\alpha$ naphthol in 5ml acetone and 5, 10, 15, 20, 25, 30, 35, 40 and $45 \mu \mathrm{l}$ of stock solution was pipetted out into eppendorff tube and phosphate buffer (50mM, pH 7.4) was added to make up to $1.3 \mathrm{ml}$ to get standard solutions of $1.3 \mathrm{ml}$ phosphate buffer containing $0.10,0.20,0.30,0.40,0.50,0.60,0.70,0.80$ and $0.90 \mu$ moles $\alpha$-napthol, respectively and blank containing 1.3 $\mathrm{ml}$ phosphate buffer only. The $200 \mu \mathrm{l}$ of staining solution was added to all the tubes and incubated at $30^{\circ} \mathrm{C}$ for 20 minutes in dark condition. Absorbance was measured at $595 \mathrm{~nm}$. The curve was plotted with OD at $595 \mathrm{~nm}$ along the $\mathrm{y}$-axis and concentration along $\mathrm{x}$-axis.

\section{Assay on cytochrome $\mathbf{P 4 5 0}$ monooxygenase}

Cytochrome P450 monooxygenase activity was measured with p-nitroanisole used as a substrate. The assay mixture was prepared by adding $10 \mu \mathrm{l}$ enzyme, $180 \mu \mathrm{l} 8 \mathrm{mM}$ pnitroanisole (dissolved in little ethonol and make up with phosphate buffer). The samples were incubated for $10 \mathrm{~min}$ at $30{ }^{0} \mathrm{C}$. The reaction was initiated by adding $10 \mu \mathrm{l}$ of $6 \mathrm{mM}$ reduced NADPH. Immediately, the observance was read by change at every 30 seconds over a period of $10 \mathrm{~min}$ at $415 \mathrm{~nm}$. Activity was calculated with an extinction coefficient of 10.00 $\mathrm{mM} / \mathrm{cm}$ was used.

The enzyme activity was calculated as follows: nanomoles of p-nitrophenol formed min-1 mg-1 protein 


$$
=\frac{\Delta \mathrm{A} 415 / \mathrm{min} \times 1000}{10.00 \times \text { protein }(\mu \mathrm{g})}
$$

\section{Results and Discussion}

Detoxification enzyme activities were determined in both field collected and susceptible laboratory reared populations of cotton leafhopper, A. biguttula biguttula

The measured activity of cytochrome P450 monooxygenase was summarized in table1. The field collected population $(14.88 \mathrm{nmol} / \mathrm{min} / \mathrm{mg}$ protein) showed highest specific activity than susceptible laboratory reared population (12.02 $\mathrm{nmol} / \mathrm{min} / \mathrm{mg}$ protein). Levels of cytochrome P450 was 1.24 fold higher in field collected population than in the susceptible population. Similar findings were reported by Kone et al. (2019) [4] wherein cytochrome P450 monooxygenase activity varied across the six field collected populations of cotton jassids in Cote d'Ivoire based on insecticide usage in a particular area. The cytochrome P450 monooxygenase activity was significantly higher (3.60 folds) in resistant strain than in the susceptible strain of Bemisia tabaci Green (Zhang et al., 2015) ${ }^{[13]}$.

Table 1: Activity of metabolic enzymes of cotton leafhopper, A. biguttula biguttula populations

\begin{tabular}{|c|c|c|c|c|c|c|}
\hline \multirow{2}{*}{ Location } & \multicolumn{2}{|c|}{ Glutathione S-transferase } & \multicolumn{2}{c|}{ Carboxylesterase } & \multicolumn{2}{c|}{ Cytochrome P450 monooxygenase } \\
\cline { 2 - 7 } & $\begin{array}{c}\text { Specific activity } \\
\text { (nmol/min/mg } \\
\text { protein) }\end{array}$ & $\begin{array}{c}\text { Fold variation as } \\
\text { compared to Lab-S }\end{array}$ & $\begin{array}{c}\text { Specific activity } \\
\text { (nmol/min/mg } \\
\text { protein) }\end{array}$ & $\begin{array}{c}\text { Fold variation } \\
\text { as compared to } \\
\text { Lab-S }\end{array}$ & $\begin{array}{c}\text { Specific activity } \\
\text { (nmol/min/mg } \\
\text { protein) }\end{array}$ & $\begin{array}{c}\text { Fold variation as } \\
\text { compared to } \\
\text { Lab-S }\end{array}$ \\
\hline Field collected population & $1021.83 \pm 5.19$ & 3.29 & $1321.97 \pm 4.20$ & 1.29 & $14.88 \pm 0.50$ & 1.24 \\
\hline Lab-S & $310.26 \pm 3.71$ & - & $1022.82 \pm 7.52$ & - & $12.02 \pm 1.73$ & - \\
\hline
\end{tabular}

Lab-S= Laboratory susceptible population

Glutathione S-transferase (GST) specific activity of field collected and laboratory populations were 1021.83 and 310.26 (nmol/min/mg protein) respectively. GST activity was 3.29 fold higher in field population than in the susceptible laboratory population. Halappa et al. (2016) ${ }^{[3]}$ who recorded higher GSTs activity and enzymatic activity ratios were noticed in the leafhopper population of Gulbarga (very high), followed by Haveri (high) and Davanagere (medium) pesticide usage areas while, lower GSTs activity and enzymatic ratios were noticed in the low pesticide usage area (Mundgod). Among the population highest GST activity was noticed in population of Nanded $(527.78 \mathrm{nmol} / \mathrm{min} / \mathrm{mg}$ protein) followed by Parbhani (475.84 $\mathrm{nmol} / \mathrm{min} / \mathrm{mg}$ protein) and Raichur (403.27 nmol/min/mg protein) which were higher compared to rest of the locations (Vimala et al., 2016) ${ }^{[12]}$.

Carboxylesterase specific activity of individuals of field collected population was 1321.97 (nmol/min/mg protein) and susceptible laboratory population recorded (1022.82 $\mathrm{nmol} / \mathrm{min} / \mathrm{mg}$ protein). Esterase activity did not differ significantly between field and susceptible population. Vimala et al. (2016) ${ }^{[12]}$ reported that esterase activity of Nanded, Raichur and Coimbatore population was higher compared to other locations. Prathibha et al. (2016) [8] revealed that esterase activity was high among all field collected populations compared to lab population and a significant correlation was found between all tested insecticides and esterase resistance in Maconellicoccus hirsutus Green. Elevated esterase activity has been implicated in resistance to insecticides of a variety of insects.

\section{Conclusion}

From the present study it can be concluded that field population showed higher activity of glutathione Stransferase, carboxylesterase and cytochrome P450 monooxygenase as compared to susceptible laboratory reared population. Elevated activity these three metabolic enzymes has been implicated in resistance to insecticides in cotton leafhopper, A. biguttula biguttula.

\section{References}

1. Chalam MS, Subbaratnam GV. Insecticide resistance in cotton leafhopper, Amrasca biguttula biguttula (Ishida) in Andhra Pradesh. Pest Management Ecology and Zoology 1999;7:105-110.
2. Chalam MSV, Subbaratnam GV, Rao GRC. Role of mixed function oxidases in imparting resistance to the cotton leafhopper, Amrasca biguttula biguttula (Ishida). Pest Management Ecology and Zoology 2001;9(1):49-53.

3. Halappa B, Patil RK. Detoxifying enzyme studies on cotton leafhopper, Amrasca biguttula biguttula (Ishida), resistance to neonicotinoid insecticides in field populations in Karnataka, India. Journal of Plant Protection Research 2016;56(4):346-352.

4. Kone PWE, Kouakou M, Mamadou D, Ochou OG. Activity of insecticide detoxification enzymes in cotton jassids: Agronomic implications for cotton pest management in Côte d'Ivoire. London Journal of Research in Science: Natural and Formal 2019;19(5):53-60.

5. Kranthi KR. Insecticide resistance management in cotton to enhance productivity, model training course on cultivation of long staple cotton, Central Institute for Cotton Research, Regional station, Coimbatore, December 15-22 2007, 214-231.

6. Kshirsagar SD, Satpute NS, Moharil MP. Monitoring of insecticide resistance in cotton leafhopper, Amrasca biguttula biguttula (Ishida). Annals of Plant Protection Science 2012;20(2):283-286.

7. Mohan S, Nandini S. A promising entry for cotton leafhopper. Pestology 2011;35(6):11-13.

8. Prathibha M, Venkatesan T, Jalali SK. Resistance in Maconellicoccus hirsutus (Green) in India to selected insecticides and quantification of detoxifying enzymes imparting resistance. Crop Protection 2016;89:116-122.

9. Praveen PM. Studies on insecticide resistance in early season sucking pests of cotton in Tamil Nadu. Ph. D. Thesis, Tamil Nadu Agricultural University, Coimbatore (India) 2003.

10. Rohini A, Prasad NVVSD, Chalam MSV. Management of major sucking pests in cotton by insecticides. Journal of Cotton Research and Development 2012;20(1):102-106.

11. Santhini S, Uthamasamy S. Susceptibility of cotton leafhopper (Amrasca devastans) to insecticides in Tamil Nadu. Indian Journal of Agricultural Sciences 1997;67:330-331.

12. Vimala, Bheemanna M, Rajesh C, Reddy RS. Toxicity of neonicotinoids and conventional insecticides to south Indian populations of cotton leafhopper (Amrasca 
biguttula biguttula). Research Journal of Chemistry and Environment 2016;20(10):21-25.

13. Zhang BZ, Kong FC, Zeng XN. Detoxification enzyme activity and gene expression in diafenthiuron resistant whitefly, Bemisia tabaci. Journal of Agricultural Sciences 2015;7(9):66-76. 